\title{
Assessment of the relationships between optimistic life orientation and hope levels and health-related quality of life in parents
}

\author{
Ece Elif Ocala, Hatice Aygarb, Emrah Atayc, Gulsum Ozturk Emirald, \\ Muhammed Fatih Onsuze, Selma Metintas ${ }^{\mathrm{f}}$
}

\begin{abstract}
a Res.Asst,Osmangazi University, Medicine Faculty, Department of Public Health, Eskişehir, Turkey.
b Res.Asst, Osmangazi University, Medicine Faculty, Department of Public Health, Eskişehir, Turkey.

c Res.Asst, Osmangazi University, Medicine Faculty, Department of Public Health, Eskişehir, Turkey.

d Pub Health Spe., Çankaya District Health Directorate, Ankara, Turkey.

e Assoc.Prof., Osmangazi University, Medicine Faculty, Department of Public Health, Eskişehir, Turkey.

f Prof., Osmangazi University, Medicine Faculty, Department of Public Health, Eskişehir, Turkey.
\end{abstract}

Received date: 10.05.2019, Accepted date: 10.03.2020

\begin{abstract}
Objective: Approaching life with optimism and hope will increase one's psychological wellbeing and quality of life. The aim of this paper was to evaluate the association between optimism and hope levels in adults on health-related quality of life in physical and mental areas. Methods: This cross-sectional study was conducted at three different primary schools in Eskisehir with a sample of 674 parents of students. In order to collect data, a questionnaire consisting of 4 parts was formed after conducting a comprehensive literature review. The first part includes the sociodemographic characteristics of the parents, the second part of the health-related quality of life scale "Short Form 12 (SF-12)", the third part of the Life Orientation Test (LOT) and the fourth part "Dispositional Hope Scale" questions. Mann-Whitney U, Kruskal-Wallis and multiple linear regression analyzes were used to evaluate the data. Results: The ages of participants ranged from 24 to 55 years, with a mean \pm SD of $36.23 \pm 4.49$ years.The scores from the healthrelated quality of life Physical Component Summary (PCS) Score ranged from 25.0 to 63.2 with a median of 50.5, while the scores from the Mental Component Summary (MCS) Score ranged from 15.6 to 66.3 with a median of 49.5 . When both scales were taken together into a regression model, the influence of the LOT on physical health disappeared, and the effect of the
\end{abstract}

Corresponding Author: Ece Elif Ocal, Osmangazi University, Medicine Faculty, Department of Public Health, Eskişehir, Turkey. Phone: +90 222 2392979; E-mail: elifece90@hotmail.com

\section{Copyright holder Turkish Journal of Public Health}

This work is licensed under a Creative Commons Attribution-NonCommercial 4.0 International License. $(\mathrm{cc}) \mathrm{EY}-\mathrm{No}$ properly. 
Dispositional Hope Scale continued. Conclusion: Optimism and hope are closely related to one's state of health. In generally healthy groups, optimism and hope will reflect the tendency to stay

away from negative emotions and cognitions in order to protect one's health. It was concluded that in order to improve one's quality of life and health, it is important to make optimism and hopefulness a part of life.

Keywords: Optimism, quality of life, hope, Turkey

\section{Ebeveynlerde yaşama iyimserlikle yönelme ve umut düzeyleri ile sağlıkla ilgili yaşam kalitesi ilişkilerinin değerlendirilmesi}

$\ddot{0 ̈ z}$

Amaç: Hayata iyimserlik ve umutla yaklaşmak, kişinin psikolojik iyiliğini ve yaşam kalitesini artıracaktır. Çalışmada, erişkin yaş grubunda yaşama iyimserlikle yönelme ve umut düzeylerinin, fiziksel ve ruhsal alanlarda sağlıkta yaşam kalitesi ile ilişkisinin değerlendirilmesi amaçlandı. Yöntem: Kesitsel tipteki çalışma Eskişehir ilinde 3 ilkokulda 674 öğrencinin velilerinde gerçekleştirildi. Çalışmada veri toplamak amacıyla kapsamlı literatür taramasından sonra 4 bölümden oluşan anket form oluşturuldu. Birinci bölüm ebeveynlerin sosyodemografik özelliklerini/öz-soygeçmiş özelliklerini, ikinci bölüm sağlıkla ilgili yaşam kalitesi ölçeği "Short Form 12 (SF-12)", üçüncü bölüm "Yaşam Yönelim Testi'nin (YYT)" ve dördüncü bölüm ise "Sürekli Umut Ölçeği" sorularını içermekteydi. Verilerin değerlendirilmesinde Mann-Whitney U, Kruskal-Wallis ve çoklu lineer regresyon analizleri kullanıldı. Bulgular: Yaşları 24-55 arasında değişmekte olup ortalama \pm SD $36.23 \pm 4.49$ yll idi. Sağlıkta yaşam kalitesi Fiziksel Bileşen Özet Skor'dan aldıkları puanlar 25.0-63.2 arasında değişmekte olup ortanca değeri 50.5 iken, Mental Bileșen Özet Skor'dan aldıkları puanlar 15.6-66.3 arasında değişmekte olup ortanca değeri 49.5 idi. Umut duygulanımı ve iyimserliğin Mental sağlık üzerine etkisi daha fazla iken, iyimserliğin umuda göre etkisinin daha yüksek olduğu saptandı. Her iki ölçek birlikte regresyon modeline alındığında ise Yaşam yönelim testi ölçeğinin fiziksel sağlık üzerindeki etkisi ortadan kalktı, sürekli umut ölçeğinin etkisi devam etmekteydi. Sonuç: İyimserlik ve umut sağlık durumuyla yakından ilişkilidir. Genel sağlıklı gruplarda sağlığın korunması için iyimserlik ve umut duyguları, olumsuz duygu ve kognisyonlardan uzak olma eğilimini yansitacaktır. Yaşam kalitesinin iyileştirilmesi için sağlığın korunmasında iyimserlik ve umut duygulanımlarının kişilerin yaşamının bir parçası haline getirilmesinin önemli olduğu kanaatine varıldı.

Anahtar kelimeler: İyimserlik, yaşam kalitesi, umut, Türkiye

\section{Introduction}

Optimism is thought of as a conceptualized personality trait with a general expectation that results can be controlled in the face of life-events and that good things will happen in the future.1,2 It is thought that approaching life with optimism has positive effects on the physical and psychological health of individuals, since it enables individuals to develop the ability to cope with difficulties and stressful life events, as well as to plan and solve problems. ${ }^{3}$ The amount of evidence suggesting that optimism, a positive life orientation, is associated with better health outcomes is increasing continuously. In many studies, it is found that optimistic thinking creates 
higher psychological well-being in groups at risk of psychological distress and creates positive effects in the face of serious health problems, such as cardiovascular diseases and cancer. Mental optimism is also related to positive health practices, and found to create a better health-related quality of life. 4,5 Hope is different from optimism, yet functions as a structurally similar concept. ${ }^{6}$ Hope is defined as a positive state of motivation, which is based on a successful emotion and is derived interactively with the intermediaries for the goal-oriented energy and with the pathways to reach the goals. ${ }^{7}$ While hope is an element oriented toward the individual, optimism is considered to cover a broader area. ${ }^{8}$ In various studies, it was seen that hope has an effect on individuals' mental and physical health, well-being, ${ }^{9}$ life satisfaction, ${ }^{10,11}$ motivation levels, ${ }^{12}$ self-efficacy ${ }^{7}$ and quality of life. ${ }^{13}$ While a high level of hope is an indicator of high well-being, low levels are interpreted as an indicator of personal sorrow and distress. ${ }^{14}$

The goal of health services offered to communities is to increase the healthrelated quality of life of individuals. While there is no widely accepted definition for health-related quality of life, the Center for Disease Control and Prevention (CDC) defines it as the physical and mental health perception of the individual or community over time. Quality of life is conceived as a multi-dimensional structure that includes physical, psychological and social functions. ${ }^{15}$

It is reported that quality of life may be related to gender, age, education level, employment status, economic status, having chronic disease and lifestyle behaviors. ${ }^{16}$

It is presumed that approaching life with optimism and hope will increase one's psychological well-being and quality of life. As with the concepts of optimism and hope, health-related quality of life has mainly been studied in patient groups. However, measuring societies' health-related quality of life is extremely important in terms of monitoring the health of societies, determining priorities through planning programs and assessing the quality of care.
Having children is a factor that make adults more sensitive about both themselves' and their child's health. It is shown that the life quality of parents may affect or may be affected from the life quality of their children. ${ }^{17}$ So it is important to include parents in studies about quality of life.

Making these evaluations within the general public can provide incentives for life through inclusion in health empowerment efforts and the inclusion of programs that increase the level of hope. In this study, it was aimed to show the association of optimism and hope levels in the adult age group on the quality of life in the physical and mental areas.

\section{Methods}

\section{Study population}

The study was a representative crosssectional study conducted on a middle-age group of adults selected from the general population. Primary education is compulsory in Turkey, ${ }^{18}$ and every one in ten people are a primary school student. ${ }^{19}$ For the primary school period, students are obligated to register with the school closest to their residence. ${ }^{20}$ This can be regarded as an indicator of the socio-economic status of the residential areas of the schools and the people living in the area. Therefore, parents whose children were attending primary schools formed the study population. Eskisehir, where the study was conducted, is a province located in Central Anatolia with a total population of 844,842 people and is a reflection of the developed regions of Turkey. ${ }^{21}$ During the 2017 academic year, according to the records of Eskisehir Provincial Directorate of National Education, there were 153 primary schools and 38,436 primary school students in the province. ${ }^{19}$

\section{Ethical approval}

In order to conduct the study, ethical approval was obtained from the Eskisehir Osmangazi University Educational Sciences Institute Educational and Humanitarian Ethics Board (date: 03.04.2017, number of 
the approval: 2017/2-9), official permits were obtained from the National Education Directorates and school administrations. Prior to the study, informed consent of the participants was ascertained and those who gave their written consent formed the work group.

\section{Study design}

The sample size of the study was calculated to be 609 for determining a difference of 4point increase in the SF-12 Health Survey (SF-12), between individuals with high levels of optimism and hope and individuals with low levels by assuming alpha error as 0.05 and the study power as $80 \%$ (standard error of 25 points). The return rate of the questionnaire was accepted as $85 \%$, so, a total of 700 people were taken into the study.

In the study, a two-step stratified sampling method was applied. In the first step of the study, a district (Tepebasi) was selected from two central districts. The districts of the schools which the students were attending throughout the province were divided into three groups as low, middle and high, according to the socioeconomic status of the people living in the area and the information received from the national education directorate. In recruiting schools for the study, one school from each socio-economic layer was selected by drawing lots.

The researchers went to schools for data collection according to the calendar determined by the school administrators. Envelopes including questionnaire forms and informed volunteer forms were distributed to students and their parents were asked to fill in the relevant information. One child from each family was included in the study. Two days later, the schools were visited again, and the forms were collected. Second and third visits were made in schools having low response rates. Participation rate was $96.2 \%$ (674/700).

\section{Study procedure}

Following a comprehensive literature search, a four-part questionnaire form was created in order to collect data. ${ }^{22-25}$ The first part questioned the sociodemographic characteristics and also personal and family history characteristics of the parents (e.g., age, gender, educational status, working status, income status, residence status, type of heating, number of rooms, etc., presence of chronic illness in themselves or in their children, etc.).

While, the second part included the SF-12, the third part comprised of the Life Orientation Test (LOT) and the fourth part contained the "Dispositional Hope Scale" questions. The SF-12 was developed selecting 12 questions from the subsections of the 36-item Short Form Health Survey (SF-36) by Ware et al., in 1994.22 SF-12 evaluates one's quality of life for the last four weeks, without focusing on a specific age or disease group. Unlike SF-36, SF-12 evaluates the Physical Component Summary (PCS) Score and Mental Component Summary (MCS) Score areas with a single parameter. The score that is achieved from the summary score may vary from 0 to 100 points, and as the quality of life increases, the score increases. ${ }^{22}$

LOT was developed by Scheier and Carver in 1987, and its Turkish version's validity and reliability study was conducted by Aydın and Tezer in 1991. The LOT consists of 12 items. Four of the items reflect a positive (optimistic) viewpoint of life, four reflect negative (pessimistic) points of view, and the other four items act as fillers. The items are in 5-point Likert type, answered as "0-strongly disagree" and "4-strongly agree". The scores that can be taken from the LOT range from 0 to 32 , and increased levels indicates the increased level of a positive (optimistic) point of view of life. 25,26

Dispositional Hope Scale was developed by Snyder et al. in 1991 with the aim of determining hope levels in individuals aged 15 and older, and its reliability and validity studies in Turkey were conducted by Tarhan and Bacanll in 2015. The scale consists of 12 items in total categorized by 2 dimensions called the Alternative Ways Thinking and Actuating Thinking. Each dimension contains 4 items, and the remaining 4 items are fillers. Fillers are not scored on the scale of the octal 
Likert type. The scores from the subdimensions are added, and a total score is obtained. Scores that can be taken from the scale are between 8 and 64 points. As the level of hope increases, the score on the scale increases. ${ }^{23,24}$

To determine the socioeconomic levels of individuals, a composite index was used which was obtained from the data, the regions they live in (low: 0 , high: 1 ), income status (poor:0, moderate:1, high:2), employment status (not working:0, irregular income:1, regular income:2), education level (primary education: 0 , high school: 1, university: 3), warming condition (stove: 0, heater: 1) and housing characteristics (rent:0, own:1). ${ }^{27}$ The total score that could be obtained ranged from 110. The individuals were divided into two groups, the median value of the total score who had 5 or more points are regarded as having a high socio-economic level and who had lower than 5 points were regarded as having a low socio-economic level.

\section{Statistical analysis}

Analysis of the obtained data was done by using the Statistical Package for the Social Sciences (SPSS) (15.0) package program. The data of the study group were given as measures of central tendency (proportion, mean, ratio) and dispersion (Standard Deviation, range). Prior to the analysis of quantitative data, their compliance with normal distribution was tested with the Kolmogorov-Smirnov normality test and graphs. The Mann-Whitney U and KruskalWallis tests were used to compare median scores, since the data did not show a normal distribution.

Multiple Linear Regression analysis was also applied to determine the factors that affect the health-related quality of life scale score sub dimensions. The log of SF-12 sub dimension scores, which were dependent variables, were calculated, and adjusted to normal distribution. When applying multiple linear regression model, the model was created by using variables that valued $P \leq 0.10$ in single analysis. The level of statistical significance was accepted as $\mathrm{P} \leq 0.05$.
After all other variables were fixed in the model, the effect of 1 Standard deviation difference on optimism and hope scores was evaluated by using multi-linear regression model. All SF-12 sub dimensions were modeled as continuous outcomes. Both optimism and hope were included in all regression models as continuous predictors.

\section{Results}

Of the study group, $70.9 \%(n=478)$ were female. Their ages ranged from 24 to 55 years with a mean of $36.23 \pm 4.49$ years. Of the participants, $44.6 \%(\mathrm{n}=301)$ had primary or lower education, $42.1 \%$ had low socioeconomic level, 53\% had 2 children, $77.9 \%$ were a nuclear family type, $11.4 \%$ had a chronic disease and $10.1 \%$ had a child with chronic disease. Of the study group, $44.4 \%$ had a regular income, $65.0 \%$ owned their own house and $30.1 \%$ had 4 or more rooms in their house, $75.5 \%$ reported that their house was warmed up with heating.

The scores obtained from the healthrelated quality of life PCS Score ranged from 25.0 to 63.2 with a median of 50.5, while the scores of the MCS Score ranged from 15.6 to 66.3 with a median of 49.5 .

The mean and SD of scores were $48.35 \pm 7.62$ for physical health sub dimension and $47.92 \pm 9.31$ for mental health sub dimension. The physical health dimension score of $39.5 \%$ of the individuals were lower than the mean value, while the mental health subdimension score of $43.8 \%$ were lower than the mean value.

The comparison of the median scores of the study group obtained from Physical and Mental Component Summary Scores of Health-related quality of life according to sociodemographic characteristics is presented in Table 1.

The health-related quality of life Physical and Mental Component Summary Scores were found to be lower in the ones having low level of education and socioeconomic level, having three or more children, and having a physician-diagnosed chronic disease in themselves or their children. 
Table 1. The comparison of the scores obtained from physical and mental component summary scores of health-related quality of life according to sociodemographic characteristics

\begin{tabular}{|c|c|c|c|c|c|}
\hline \multicolumn{2}{|c|}{$\begin{array}{l}\text { Sociodemographic } \\
\text { characteristics }\end{array}$} & \multirow{2}{*}{$\begin{array}{c}\begin{array}{c}\text { Physical } \\
\text { Component } \\
\text { Summary Score } \\
\text { Median } \\
\text { (minimum- } \\
\text { maximum) }\end{array} \\
50.4(25.2-63.2) \\
50.9(25.0-60.6)\end{array}$} & \multirow{2}{*}{$\begin{array}{c}\mathbf{p} \\
0.624\end{array}$} & \multirow{2}{*}{$\begin{array}{c}\begin{array}{c}\text { Mental } \\
\text { Component } \\
\text { Summary Score } \\
\text { Median } \\
\text { (minimum- } \\
\text { maximum) }\end{array} \\
49.6(15.6-66.3) \\
49.5(19.9-65.0)\end{array}$} & \multirow{2}{*}{$\begin{array}{c}\mathbf{p} \\
0.398\end{array}$} \\
\hline Gender & $\begin{array}{c}\text { Female } \\
\text { Male }\end{array}$ & & & & \\
\hline $\begin{array}{l}\text { Age group } \\
\text { (year) }\end{array}$ & $\begin{array}{l}24-39 \\
40-55\end{array}$ & $\begin{array}{l}50.7(25.2-63.2) \\
49.9(25.0-60.6)\end{array}$ & 0.332 & $\begin{array}{l}49.8(15.6-66.3) \\
48.5(19.9-62.1)\end{array}$ & 0.470 \\
\hline Education level & $\begin{array}{l}\text { Primary school } \\
\text { High school } \\
\text { University }\end{array}$ & $\begin{array}{l}48.4(27.0-61.8) \\
50.8(25.0-60.5) \\
52.3(25.2-63.2)\end{array}$ & $<0.001$ & $\begin{array}{l}46.9(19.9-66.3) \\
51.1(18.4-63.8) \\
51.0(15.6-61.9)\end{array}$ & $<0.001$ \\
\hline $\begin{array}{l}\text { Socioeconomic } \\
\text { level }\end{array}$ & $\begin{array}{l}\text { Low } \\
\text { High }\end{array}$ & $\begin{array}{c}48.4(25.0-61.8) \\
51.3(25.1-63.2)\end{array}$ & $<0.001$ & $\begin{array}{l}47.1(18.4-66.3) \\
50.8(15.6-63.8)\end{array}$ & $<0.001$ \\
\hline Family type & $\begin{array}{l}\text { Extended family } \\
\text { Nuclear family } \\
\text { Broken family }\end{array}$ & $\begin{array}{c}49.1(25.0-60.6) \\
50.8(25.1-61.8) \\
50.5(27.0-63.2)\end{array}$ & 0.719 & $\begin{array}{l}46.5(18.4-63.8) \\
50.1(22.7-66.3) \\
50.2(15.6-65.0)\end{array}$ & 0.004 \\
\hline $\begin{array}{l}\text { Number of } \\
\text { children }\end{array}$ & $\begin{array}{c}1 \\
2 \\
3 \text { and above }\end{array}$ & $\begin{array}{c}51.5(28.0-63.2) \\
50.8(25.0-60.6) \\
47.9(25.1-60.6)\end{array}$ & $<0.001$ & $\begin{array}{l}51.5(15.6-65.0) \\
50.1(18.4-66.3) \\
46.2(19.9-65.1)\end{array}$ & 0.003 \\
\hline $\begin{array}{l}\text { The presence of } \\
\text { a physician- } \\
\text { diagnosed } \\
\text { chronic disease }\end{array}$ & $\begin{array}{l}\text { No } \\
\text { Yes }\end{array}$ & $\begin{array}{l}50.6(25.0-63.2) \\
48.8(27.1-61.8)\end{array}$ & $<0.001$ & $\begin{array}{l}49.7(15.6-66.3) \\
46.0(19.9-61.9)\end{array}$ & 0.011 \\
\hline $\begin{array}{l}\text { The presence of } \\
\text { a physician- } \\
\text { diagnosed } \\
\text { chronic disease } \\
\text { in their } \\
\text { children }\end{array}$ & $\begin{array}{l}\text { No } \\
\text { Yes }\end{array}$ & $\begin{array}{l}50.8(25.0-63.2) \\
45.4(25.2-60.5)\end{array}$ & $<0.001$ & $\begin{array}{l}49.8(27.3-62.2) \\
44.5(24.3-63.3)\end{array}$ & 0.006 \\
\hline
\end{tabular}

The scores of the study group obtained from the LOT ranged from 3.0 to 32.0 with a median of 20.0 and with a mean of $20.14 \pm 4.83$. The scores obtained from Dispositional Hope Scale ranged from 8.0 to 64.0 and the median and mean values were 52.0 and 50.95 \pm 8.78 , respectively. A moderate positive correlation was found between the participants' scores taken from the LOT and the Dispositional Hope Scale ( $\mathrm{r}$ $=0.418, \mathrm{P}<0.001)$. The comparison of the score medians of the study group obtained from the Life Orientation Test and Dispositional Hope Scale according to sociodemographic characteristics is presented in Table 2. 
Table 2. The comparison of the scores obtained from the Life Orientation Test and Dispositional Hope Scale according to sociodemographic characteristics

\begin{tabular}{|c|c|c|c|c|c|}
\hline \multicolumn{2}{|c|}{$\begin{array}{l}\text { Sociodemographic } \\
\text { characteristics }\end{array}$} & \multirow{2}{*}{$\begin{array}{c}\text { Life } \\
\text { Orientation } \\
\text { Test } \\
\text { Median } \\
\text { (minimum- } \\
\text { maximum) }\end{array}$} & \multirow{2}{*}{$\begin{array}{c}\mathbf{p} \\
0.388\end{array}$} & \multirow{2}{*}{$\begin{array}{c}\begin{array}{c}\text { Dispositional } \\
\text { Hope Scale } \\
\text { Median } \\
\text { (minimum- } \\
\text { maximum) }\end{array} \\
51.0(8.0-64.0) \\
53.0(8.0-64.0)\end{array}$} & \multirow{2}{*}{$\begin{array}{c}\mathbf{p} \\
0.807\end{array}$} \\
\hline Gender & $\begin{array}{l}\text { Female } \\
\text { Male }\end{array}$ & & & & \\
\hline $\begin{array}{l}\text { Age group } \\
\text { (year) }\end{array}$ & $\begin{array}{l}24-39 \\
40-55\end{array}$ & $\begin{array}{c}20.0(3.0-32.0) \\
19.0(10.0-31.0)\end{array}$ & 0.499 & $\begin{array}{c}52.0(8.0-64.0) \\
50.0(25.0-64.0)\end{array}$ & 0.365 \\
\hline Education level & $\begin{array}{c}\text { Primary school } \\
\text { High school } \\
\text { University }\end{array}$ & $\begin{array}{l}19.0(5.0-32.0) \\
21.0(5.0-32.0) \\
22.0(3.0-31.0)\end{array}$ & $<0.001$ & $\begin{array}{c}51.0(8.0-64.0) \\
51.0(8.0-64.0) \\
53.0(34.0-64.0)\end{array}$ & $<0.001$ \\
\hline $\begin{array}{l}\text { Socioeconomic } \\
\text { level }\end{array}$ & $\begin{array}{l}\text { Low } \\
\text { High }\end{array}$ & $\begin{array}{l}19.0(9.0-32.0) \\
21.0(3.0-32.0)\end{array}$ & 0.002 & $\begin{array}{l}50.0(8.0-64.0) \\
53.0(8.0-64.0)\end{array}$ & $<0.001$ \\
\hline Family type & $\begin{array}{l}\text { Extended family } \\
\text { Nuclear family } \\
\text { Broken family }\end{array}$ & $\begin{array}{c}18.0(5.0-32.0) \\
21.0(3.0-32.0) \\
20.0(10.0-31.0)\end{array}$ & 0.003 & $\begin{array}{c}51.5(24.0-64.0) \\
52.0(8.0-64.0) \\
53.0(14.0-64.0)\end{array}$ & 0.521 \\
\hline $\begin{array}{l}\text { Number of } \\
\text { children }\end{array}$ & $\begin{array}{c}1 \\
2 \\
3 \text { and above }\end{array}$ & $\begin{array}{c}21.0(11.0-32.0) \\
21.0(3.0-32.0) \\
19.0(6.0-32.0)\end{array}$ & $<0.001$ & $\begin{array}{c}53.0(21.0-64.0) \\
52.0(8.0-64.0) \\
51.0(14.0-64.0)\end{array}$ & 0.012 \\
\hline $\begin{array}{l}\text { The presence of } \\
\text { a physician- } \\
\text { diagnosed } \\
\text { chronic disease }\end{array}$ & $\begin{array}{l}\text { No } \\
\text { Yes }\end{array}$ & $\begin{array}{l}20.0(3.0-32.0) \\
20.0(10.0-31.0)\end{array}$ & 0.629 & $\begin{array}{l}52.0(8.0-64.0) \\
51.0(8.0-64.0)\end{array}$ & 0.240 \\
\hline $\begin{array}{l}\text { The presence of } \\
\text { a physician- } \\
\text { diagnosed } \\
\text { chronic disease } \\
\text { in their } \\
\text { children }\end{array}$ & $\begin{array}{l}\text { No } \\
\text { Yes }\end{array}$ & $\begin{array}{c}20.0(3.0-32.0) \\
19.0(12.0-32.0)\end{array}$ & 0.279 & $\begin{array}{l}52.0(8.0-64.0) \\
50.0(8.0-64.0)\end{array}$ & 0.003 \\
\hline
\end{tabular}

The medians of the scores obtained from the LOT and the Dispositional Hope Scale were found to be lower in those having a low level of education, low socioeconomic level, and 3 or more children.

It was observed that hope levels of the individuals were low only in the case of a presence of a physician-diagnosed chronic disease in their children.

The results of the multiple regression model showing the relationship between the scores of health-related qualities of life Physical and Mental Component Summary Scores and the Life Orientation Test and Dispositional Hope Scale are presented in Table 3. 
Table 3. The adjusteda Regression Coefficients of the multiple linear regression model showing the relationship between the health-related quality of life Physical and Mental Component Summary Scores and the Life Orientation Test and Dispositional Hope Scale

\begin{tabular}{lll}
\hline $\begin{array}{l}\text { Predictor Variables } \\
\text { Unstandardized Beta (95\% CI) }\end{array}$ & \multicolumn{1}{c}{$\begin{array}{c}\text { Physical Component } \\
\text { Summary Score }\end{array}$} & $\begin{array}{c}\text { Mental Component } \\
\text { Summary Score }^{+}\end{array}$ \\
\hline Life Orientation Test & $0.059^{*}(0.011-0.107)$ & $0.253^{* * *}(0.195-0.311)$ \\
Per 1 SD unit ${ }^{++}$ & 0.008 & 0.027 \\
\hline Dispositional Hope Scale & $0.116^{* * *}(0.057-0.175)$ & $0.264^{* * *}(0.190-0.338)$ \\
Per 1 SD unit ${ }^{++}$ & 0.019 & 0.046 \\
\hline Life Orientation Test & $0.033(-0.017-0.083)$ & $0.207^{* * *}(0.147-0.268)$ \\
Dispositional Hope Scale & $0.103^{* *}(0.041-0.165)$ & $0.183^{* * *}(0.107-0.258)$ \\
Per 1 SD unit ${ }^{++}$ & & \\
Life Orientation Test & 0.005 & 0.023 \\
Dispositional Hope Scale & 0.016 & 0.030 \\
\hline
\end{tabular}

a Adjusted according to age, gender, educational level (primary, high school, university), number of children (1, 2, 3 and more), socioeconomic status, the presence of a physician-diagnosed chronic disease in the participants, and the presence of a physician-diagnosed chronic disease in their children.

+ ; converted in $\log _{10}$ base for linear regression.

++ ; The expected average change for 1 SD change, 4.83 for Life Orientation Test, 8.78 for Dispositional Hope Scale

$*<0.05, * *<0.01, * * *<0.001$

Adjusted regression coefficients were obtained via multiple linear modeling. The effect of 1 Standard deviation difference on optimism and hope scores was also estimated by holding all other variables in the model constant. It is estimated that a 4.83-point increment in optimism was associated with a $0.008 \log 10$ unit higher PCS score and a $0.027 \log 10$ unit higher MCS score. On the other hand, it is also estimated that an 8.78-point increment in hope was associated with a $0.019 \log 10$ unit higher PCS score and a $0.046 \log 10$ unit higher MCS score.

The positive impact of optimism and hope was observed on health-related quality of life Physical and Mental Component Summary Scores. While the influence of hope and optimism on mental health was higher, the influence of optimism was found to be higher than that of hope. When both scales were taken together into the regression model, the influence of the
LOT on physical health disappeared, and the effect of the Dispositional Hope Scale persisted.

\section{Discussion}

The concepts of both optimism and pessimism, which represent expectations towards the future, are essential to understand the forms of human behavior. It is suggested that human behavior is shaped by the value of the objectives. ${ }^{28}$ Individuals need to be motivated and hopeful to achieve a desired goal. Although the concepts of optimism and hope are confused, in fact, hope is indeed a positive emotional source that feeds optimism. ${ }^{29}$

In the study, the association of optimism and hope feelings in the parents having school aged children on maintaining functional health status was shown in a group which represents the population. The study group consists of the parents of the 
children and $70 \%$ of the parents were women. The study contributes to the evidence for the role of optimistic explanatory style (the optimistic approach) in the protection and maintenance of health. Our findings, as in other studies, show that optimism has a similar relationship with hope. ${ }^{28-30}$ Our study group has shown that optimism has an association on its own, independently of other factors, on the maintenance of mental subdimension of one's quality of life. However, as opposed to our hypothesis, when the impact on the physical subdimension of health-related quality of life was assessed, optimism leaves its effect only on the hope emotion. This relationship may not have been demonstrated due to the strength of the determinants of physical health on the presence of a chronic disease in a person and/or his/her child. Since physical health is affected by more bodily causes, optimism loses its influence when hope comes into play, because hope is the source of motivation for any treatment goal in the name of treating the underlying pathology. Mental health is related to both optimism and hope, because psychological problems are often influenced by individual characteristics without being dependent on an underlying physical cause. Therefore, the impact of these two interwoven concepts of positive psychology on mental health is an inevitably expected result.

The optimistic explanatory style is characterized by the belief that important consequences can be controlled and that the future will be good. Optimistic individuals are more inclined to planning and problemsolving skills; thus, their abilities to cope with difficulties and stressful life events are more developed. ${ }^{31}$ Some researchers have argued that optimism is an indicator of the absence of neurotic and negative emotions. $^{32}$ According to this view, optimism may be related to health status because it reflects the tendency to stay away from the negative emotions and cognitions associated with spontaneous low health status.

In some studies carried out with the LOT, the subdimensions of optimism and pessimism have been evaluated separately; 33,34 but, in some other studies it has been scored on the basis of total optimism scores .5,31,35 The results of our study conducted in the middle aged adult group are comparable to the optimism scores of the Normative Aging Study in terms of generalizability. Although our age groups are different from the ones in the aforementioned study, the mean and standard deviation values of the scores obtained from the LOT are similar. While, the mean was 20.14 in our study, it was 21.50 in the Normative Aging Study and the standard deviations were 4.83, 4.33, respectively. ${ }^{31}$

Many studies have shown that health-related quality of life is significantly influenced by socio-economic status, education level, and housing conditions. ${ }^{16,36}$ In addition, it is stated that health-related quality of life is also prominently reduced by the presence of a chronic disease. ${ }^{5}$ In this study, it has been shown that mental and physical subdimensions of health-related quality of life are also related to the socioeconomic level, education level, the number of children in the family, as well as the presence of a chronic disease in themselves or in their children. Based on the evidence obtained and according to the study results, in order to show the influence of optimism and hopefulness on health-related quality of life. the factors that might be related to health-related quality of life are adjusted.

The number of studies where optimism and hope are examined together is very small. However, optimism and hope are emotions in the same direction, affecting human life in a similar way. ${ }^{30}$ In the study, it was shown that the level of optimism and hope was influenced by socio-economic level, education level, and the number of children in the family. While the relationship between optimism and the presence of a chronic disease in themselves or in their children was not shown, the negative impact of the presence of a chronic disease in their children on the level of hope was demonstrated. At this point, the role of the concept of hope as an element oriented towards the individual him/herself becomes more evident. 
The main limitation of the study was that it was a cross-sectional study, carried out on only on a sample of middle-aged adults whose children were attending primary schools. Further research could widen the sample to increase the applicability of the results.

\section{Conclusion}

According to the results of the study, optimism and hope are closely related to one's health status. In general, in healthy groups, optimism and feelings of hope will reflect the tendency to stay away from negative emotions and cognitions for the protection of health. It was concluded that it is important to make optimism and feelings of hope a part of an individual's life to protect health and improve the quality of life. To put into practice an approach for early detection of despair and pessimism in a human being is of utmost importance, since this approach can prevent functional regression and increase or protect the independence of the individual.

Conflict of Interest: The authors declare no conflict of interest.

Financial Disclosure: The authors declared that this study has received no financial support.

\section{References}

1. Harris P, Middleton W. The illusion of control and optimism about health: On being less at risk but no more in control than others. $\mathrm{Br} J$ Soc Psychol. 1994;33(4):369-86. PMID: 7842244; doi: $\quad 10.1111 / j .2044-$ 8309.1994.tb01035.x.

2. Scheier MF, Carver CS. Optimism, coping, and health: assessment and implications of generalized outcome expectancies. Health Psychol. 1985;4(3):219-47. PMID: 4029106; doi: 10.1037//0278-6133.4.3.219.

3. Chang EC, D'Zurilla TJ, Maydeu-Olivares A. Assessing the dimensionality of optimism and pessimism using a multimeasure approach. Cognit Ther
Res. 1994;18(2):143-60. doi: 10.1007/BF02357221. Available from: https://link.springer.com/article/10.1 007/BF02357221. Accessed in 2018 (May 25).

4. Uchmanowicz I, Gobbens RJ. The relationship between frailty, anxiety and depression, and health-related quality of life in elderly patients with heart failure. Clin Interv Aging. 2015;10:1595-1600. PMID: 26491276; doi: $\underline{10.2147 / C I A . S 90077}$

5. Kepka, S., Baumann, C., Anota, A., et al. The relationship between traits optimism and anxiety and health-related quality of life in patients hospitalized for chronic diseases: data from the SATISQOL study. Health Qual Life Outcomes. 2013;11:134. PMID: 23914779; doi: 10.1186/1477-7525-11134.

6. Bailey TC, Eng W, Frisch MB, Snyder C. Hope and optimism as related to life satisfaction. J Posit Psychol. 2007;2(3):168-75. doi: $10.1080 / 17439760701409546$.

7. Snyder CR. Hope theory: Rainbows in the mind. Psychol Inq. 2002;13(4):24975. 10.1207/S15327965PLI1304_01.

8. Dedeoğlu T, Özdevecioğlu M, Oflazer S. Örgütlerde Ise Gömülmüslügün (Job Embededness) Çalisanlarin Is Ve Yasam Kalitesi Üzerindeki Etkisi: İyimserliğin Rolü 1. Erciyes Üniversitesi İktisadi ve İdari Bilimler Fakültesi Dergisi. 2016(47):135-46. Available from: http://dergipark.ulakbim.gov.tr/erciyes iibd/article/view/5000191519/500016 7225. Accessed in 2018 (May 25).

9. Kato T, Snyder CR. The relationship between hope and subjective wellbeing: Reliability and validity of the dispositional hope scale, Japanese version. Japanese Journal of Psychology. 2005;76(3):227-234. doi: 10.4992/jjpsy.76.227. Available from: http://psycnet.apa.org/record/200513931-004. Accessed in 2018 (May 28).

10. Bailey TC, Snyder CR. Satisfaction with life and hope: a look at age and marital 
status. Psychol Rec. 2007;57(2):233-40. doi: 10.1007/BF03395574.

11. Cole S. Living in hope: Tourism and poverty alleviation in Flores. 2008. In: Burns PM, Novelli M, editors. Tourism Development: Growth, Myths and Inequalities. Oxford: CABI. ISBN: 9781845934255.

12. Snyder CR, LaPointe AB, Jeffrey Crowson J, Early S. Preferences of high-and lowhope people for self-referential input. Cogn Emot. 1998;12(6):807-23. doi: $10.1080 / 026999398379448$.

13. Fitzgerald Miller J. Hope: a construct central to nursing. Nurs forum. 2007;42(1):12-19. PMID: 17257391; Doi: $\quad 10.1111 /$ j.17446198.2007.00061.x.

14. Martin MW. Happiness and virtue in positive psychology. J Theory Soc Behav. 2007;37(1):89-103. doi: 10.1111/j.1468-5914.2007.00322.x. Available from: https://onlinelibrary.wiley.com/doi/full /10.1111/j.1468-5914.2007.00322.x. Accessed in 2018 (May 25).

15. Health-Related Quality of Life. HRQOL Concepts. Available from: https://www.cdc.gov/hrqol/concept.ht m. Accessed in 2018 (May 25).

16. Mier, N., Ory, MG., Zhan, D., Conkling, M., Sharkey, JR., \& Burdine, JN. Healthrelated quality of life among Mexican Americans living in colonias at the Texas-Mexico border. Soc Sci Med. 2008;66(8):1760-71. PMID: 18261832; doi: 10.1016/j.socscimed.2007.12.017.

17. Mugno, D., Ruta, L., D'Arrigo, V. G., \& Mazzone, L. Impairment of quality of life in parents of children and adolescents with pervasive developmental disorder. Health and quality of life outcomes. 2007;5(1), 22

18. Ministry of National Education, 12 Yıllık Zorunlu Eğitime Yönelik Uygulamalar, Genelge. Available from: http://www.meb.gov.tr/haberler/2012 112 YillikZorunluEgitimeYonelikGenelge. pdf. Accessed in 2018 (May 25).
19. National Education Statistics Formal Education 2016/'17. Available from: https://sgb.meb.gov.tr/meb iys dosyala r/2017 09/08151328 meb istatistikleri orgun egitim 2016 2017.pdf. Accessed in 2018 (May 25).

20. Ministry of National Education, 12 Yll Zorunlu Eğitim, Sorular-Cevaplar. Available from: http://www.meb.gov.tr/duyurular/duy urular2012/12yil soru cevaplar.pdf Accessed in 2018 (May 25).

21. Turkish Statistical Institute. 2017. (2018, May 28). Retrivied from http://www.tuik.gov.tr/PreIstatistikTab lo.do?istab_id=1590.

22. Ware J Jr, Kosinski M, Keller SD. A 12Item Short-Form Health Survey: construction of scales and preliminary tests of reliability and validity. Med Care. 1996;34(3):220-33. PMID: 8628042.

23. Tarhan S. \& Bacanlı H. (2015) . Sürekli Umut Ölçeği'nin Türkçe'ye uyarlanması: Geçerlik ve güvenirlik çalışması [Adaptation of dispositional hope scale into Turkish: Validity and reliability study]. The Journal of Happiness \& WellBeing. 3(1), 1-14 ISSN: 2147-561X. Retrieved from http://www.journalofhappiness.net/fro ntend/articles/pdf/v03i01/1.pdf .

24. Snyder CR., Harris C., Anderson JR., et al. The will and the ways: Development and validation of an individual-differences measure of hope. J Pers Soc Psychol. 1991;60(4):570-85. PMID: 2037968; doi: 10.1037/0022-3514.60.4.570.

25. Scheier ME, Carver CS. Dispositional optimism and physical well-being: The influence of generalized outcome expectancies on health. J Pers. 1987;55(2):169-210. doi: 10.1111/j.1467-6494.1987.tb00434.x. Available from: https://onlinelibrary.wiley.com/doi/pdf /10.1111/j.1467-6494.1987.tb00434.x. Accessed in 2018 (May 25).

26. Aydın G, Tezer E. İyimserlik, sağlık sorunları ve akademik bașarı ilișkisi. Psikoloji Dergisi. 1991;7(26):2-9. 
Available from: http://www.turkpsikolojiyazilari.com/P DF/TPD/26/06.pdf. Accessed in 2018 (May 25).

27. Yu, M., Tatalovich, Z., Gibson, J. T., \& Cronin, K. A. (2014). Using a composite index of socioeconomic status to investigate health disparities while protecting the confidentiality of cancer registry data. Cancer Causes \& Control. 2014;25(1):81-92. doi: 10.1007/s10552-013-0310-1.

28. CERAN SÖ. The Role of Hope and Coping Styles in Optimism [ thesis]. Ankara: Middle East Technical University; 2013.

29. Dursun P. The role of meaning in life, optimism, hope, and coping styles in subjective well-being [thesis]. Ankara: Middle East Technical University; 2012.

30. Gallagher MW, Lopez SJ. Positive expectancies and mental health: Identifying the unique contributions of hope and optimism. J Posit Psychol. 2009;4(6):548-56. doi: $10.1080 / 17439760903157166$.

31. Achat H, Kawachi I, Spiro A, DeMolles DA, Sparrow D. Optimism and depression as predictors of physical and mental health functioning: the Normative Aging Study. Ann Behav Med. 2000;22(2):127-30. PMID: 10962705; doi: 10.1007/BF02895776.

32. Scheier MF, Carver CS, Bridges MW. Distinguishing optimism from neuroticism (and trait anxiety, selfmastery, and self-esteem): a reevaluation of the Life Orientation Test. J Pers Soc Psychol. 1994;67(6):1063. PMID: 7815302; doi: 10.1037/00223514.67.6.1063.

33. Glaesmer H, Rief $\mathrm{W}$, Martin A, et al. Psychometric properties and population-based norms of the Life Orientation Test Revised (LOT-R). Br J Health Psychol. 2012;17(2):432-45. PMID: 22106985; doi: 10.1111/j.20448287.2011.02046.x.

34. Lyrakos GN, Damigos D, Mavreas V, Georgia K, Dimoliatis ID. A translation and validation study of the Life Orientation Test Revised in the Greek speaking population of nurses among three hospitals in Athens and Ioannina. Soc Indic Res. 2010;95(1):129-42. doi: 10.1007/s11205-009-9453-6.

35. Gündoğdu MH. Life Orientations among University Students [Üniversite Öğrencilerinde Yaşam Yönelimi]. Eğitim ve Bilim. 2010;35(157):192-9. Available from:

http://egitimvebilim.ted.org.tr/index.ph p/EB/article/view/425/165. Accessed in 2018 (May 25)

36. Pappa E, Chatzikonstantinidou S, Chalkiopoulos G, Papadopoulos A, Niakas D. Health-related quality of life of the roma in greece: the role of socioeconomic characteristics and housing conditions. Int J Environ Res Public Health. 2015;12(6):6669-81. PMID: 26075724; doi: 10.3390/ijerph120606669. 